\title{
A life sketch of Marta Estrada Miyares, a phytoplankton ecologist and oceanographer
}

\author{
Elisa Berdalet, Dolors Blasco, Dolors Vaqué
}

Institut de Ciències del Mar-CSIC, Pg. Marítim de la Barceloneta 37-49, 08003 Barcelona, Catalunya, Spain.

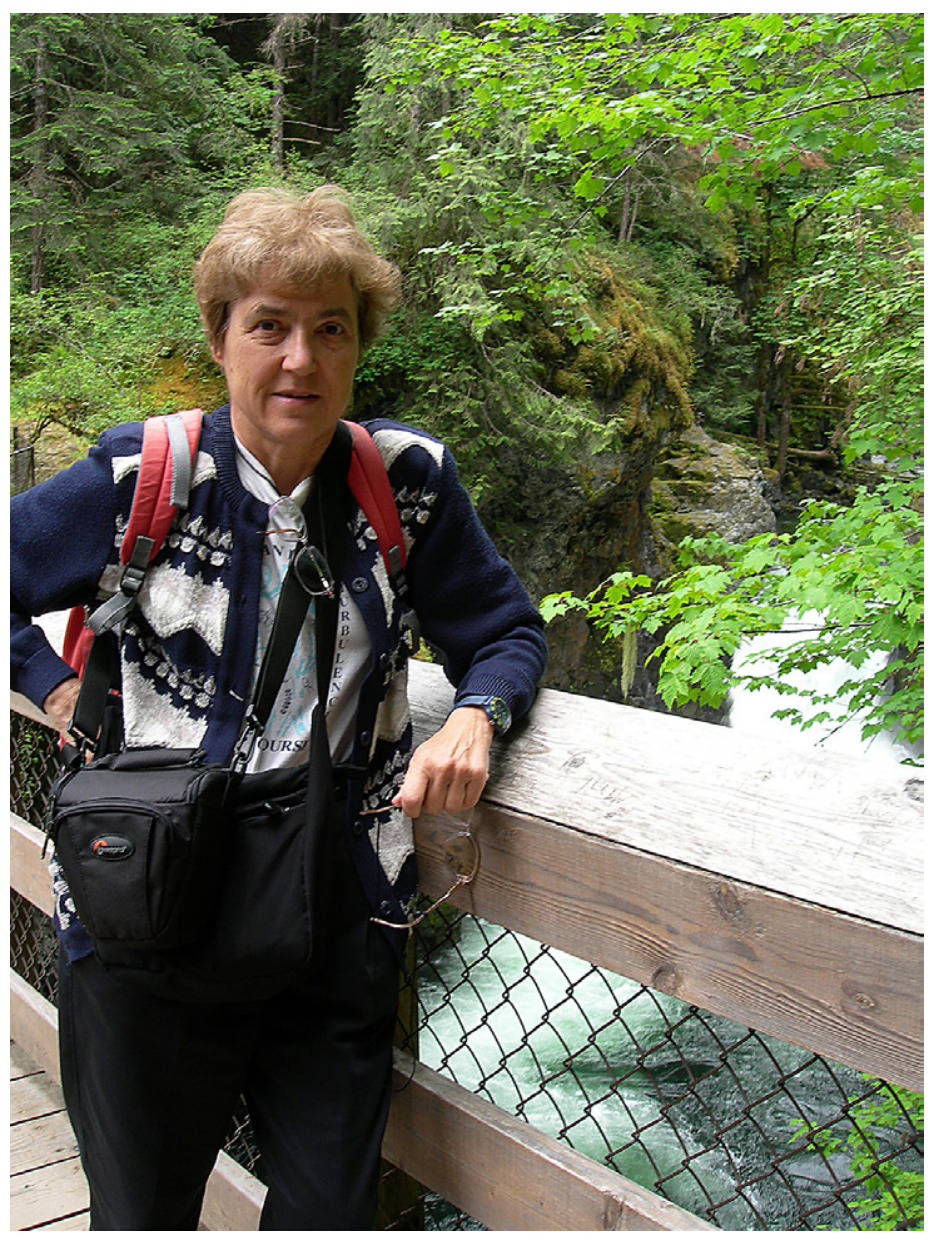

Marta Estrada Miyares was born in Granollers, Vallès Oriental (Barcelona). Her parents Feli and Josep, were well educated, had many cultural interests, were very active amateur archaeologists, and were outstanding accountant entrepreneurs. Her mother, originally from Santander (Northern Spain), moved to Barcelona as a child and was rapidly integrated to Catalan culture. Feli was a specialist in economic administration and worked actively until she was around 90 years old. With her husband, Josep, from Granollers, they ran an accounting and commercial administration agency. Josep was a pioneer archaeologist in his town, contributing to the discovery of the Granollers region's Roman history (Font and Ramon 2003). Their house became the embryo of the Granollers Museum (1976) where all findings and descriptions were carefully classified by Josep and his amateur colleagues in a professional, volunteer and philanthropic manner. Feli and Josep formally studied 


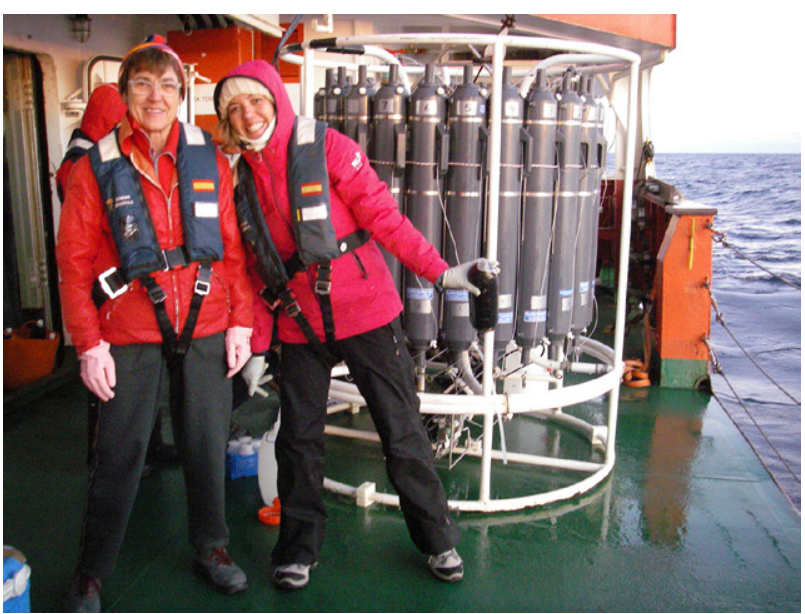

Fig. 1. - Marta Estrada in the Antarctica, with her last PhD student, Sdena Nunes (January 2015).

Archaeology at the University of Barcelona at the age of 60, after they were already well recognized for their great contributions to history and archaeology! This passion as well as their attraction to art, nature and travel, both in Catalonia and around the world, was shared with their children, Marta and Eduard. For this reason, Marta, in her youth, joined the Centre Excursionista de Catalunya (the CEC), a hiking organization founded in 1876 with the intent to integrate art, history, literature, science and nature. With the CEC, Marta enjoys many weekends and holidays in the mountains, skiing, hiking, climbing, biking and swimming. She is a very enthusiastic sportswoman following the Latin maxim, Mens sana in corpore sano (a healthy mind in a healthy body), which also helps her cope with her injured knee. Engaging herself in hiking and other sports is an example of her intrinsic continuous pursuit of personal growth and autonomy. When very young she practiced Judo to learn how to defend herself.

Marta conducted her studies at the Granollers public elementary school, Escola Municipal and her high school studies at the Institut Verdaguer in Barcelona. In 1963 she moved to Barcelona to study Biological Sciences (BS degree in 1968) and Medicine and Surgery (MD degree in 1970) at the University of Barcelona. In 1969 she graduated at the top of her class with honors, Summa Cum Laude (Matrícula de Honor) and was awarded with the National Prize (Premio Fin de Carrera) for being the top student in Health Sciences in Spain. In addition to her studies in medicine, biology, and ecology, Marta was also interested in mathematics and took several courses at the Faculty of Mathematics at the University of Barcelona. During this time she was staying in the student residence, L'Estonac. She still complains about the daily desserts of plane cookies (galetes maria), and peaches and pineapples in syrup all of which she hates. However, her friends know that Marta has a profound weakness for both whipped cream (nata) and good chocolate and that chocolate is her preferred present. As much as she loves chocolate, and indicator of her good heart is her willingness to share it with her friends when she receives it as present.
It was at the Biology Faculty of the University of Barcelona where she met Dr. Ramon Margalef, the famous Catalan ecology professor. Marta rapidly became an enthusiastic devotee of his lectures, his wise commentaries, and innovative ecological insights. At that time Dr. Margalef was also the Director of the Fisheries Research Institute (Instituto of Investigaciones Pesqueras, IIP) of the Spanish National Research Council (Consejo Superior de Investigaciones Cientificas, CSIC), the predecessor of today's Marine Sciences Institute (ICM). It was at this venerable research center, founded in 1951, where Marta conducted her doctorate investigations through the early 1970s. She focused on marine phytoplankton ecology under Dr. Margalef's supervision and this experience became the scientific reference for the length of her career. This providential scientific association between Margalef and Marta resulted in one of the most creative periods in the modern oceanography. At the IIP-CSIC, she was accompanied in her research by other brilliant Margalef students, namely Drs. Dolors Blasco, Dolors Planas, Miquel Alcaraz, Jordi Camp and Antonio Cruzado. With all of them Marta maintained a productive working relationship, shared many cruises (e.g., ATLOR, PEP, FRONTS, VARIMED, ECOANTAR, HIVERN, etc.) and holds a great friendship. In 1972, she earned a tenured research position (Científico Titular) at the CSIC and won a fellowship from the Institute of International Education to extend her doctorate research in a sojourn in the USA. In 1976 she finished her $\mathrm{PhD}$ in Biological Sciences winning the "Extraordinary Doctorate Award from the University of Barcelona”. She became Full Professor at the CSIC in 1984.

During the 1970s and 1980s Marta was an important science partner in at least two North American ocean upwelling programs, the Coastal Upwelling Ecosystems Analysis (CUEA) and the Persistent Upwelling Structures (OPUS) Programs. She participated in their ocean expeditions to the Peru, Costa Rica Dome, Northwest African, Baja California, and southern California upwelling systems. The collaboration grew out of an exchange between scientists of Prof Ramon Margalef's team from IIP and Prof Richard Dugdale's

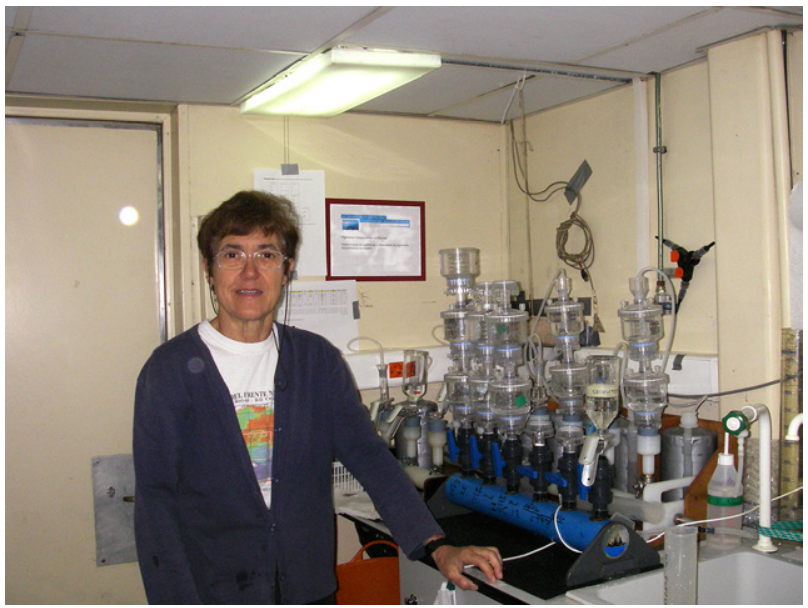

Fig. 2. - Marta Estrada in the oceanographic vessel Hespérides, during the Malaspina cruise, in front of the multi-size fractionation filtration system. February 2011. 


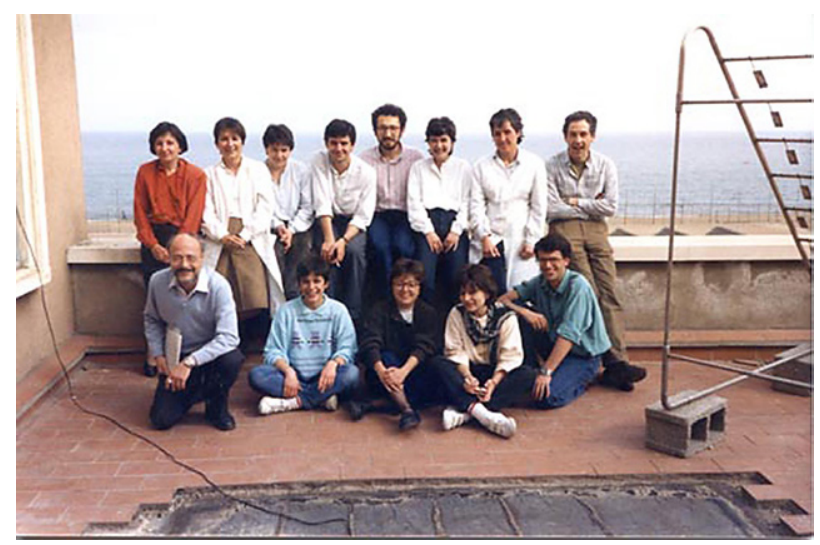

Fig. 3. - In 1988, at the terrace of the old ICM building, with several colleagues. From left to right, back line: I. Trepat, P. Andreu, E. Berdalet, E. Fernández-Suárez, E. Saiz, M. Masó, M. Estrada, J. Camp. First line: M. Alcaraz, C. Marrasé, M. Vidal, D. Vaqué, M. Latasa.

team from the University of Washington (UW). IIP scientists, principally Marta and Dolors Blasco, would participate in the USA cruises while UW scientists would participate on the Spanish ATLOR cruises to the upwelling off Northwest Africa. Marta studied phytoplankton ecophysiology and the oceanography of plankton, especially biology-physics interactions in the above mentioned upwelling areas. With her colleagues, they would measure phytoplankton productivity, biomass, nitrate uptake, and characterized the phytoplankton composition of the natural assemblages. In addition to her participation in the cruises, Marta also spent months analysing data, preparing presentations, and writing papers with her colleagues in the American oceanographic centers of the UW, Bigelow Laboratory and University of Southern California. Marta presented their results at national, international, and special upwelling symposia, and in papers co-authored among others by Blasco and Margalef (e.g. Estrada 1980, Margalef and Estrada, 1980, Blasco et al. 1980).

Marta Estrada is a Biological Oceanographer whose scientific research has been mainly focused on phytoplankton ecology. Her studies have ranged from the small ecophysiological scale to large-scale physical-biological interactions within global marine ecosystem. Furthermore, she has made special contributions to the understanding of harmful algal blooms. She has combined a variety of field and laboratory approaches and methodologies, from microscopy to satellite observations, including in depth taxonomy, statistical data analysis and modelling. Marta has published many scientific papers in top international journals, as well as books and several book chapters. Marta has led several national and international oceanographic projects, developed in the Mediterranean, Atlantic, Arctic and Antarctic Oceans. As an example, she was, together with Dr. Josefina Castellví, one of the pioneering Catalan women scientists who participated in the 1984 Spanish Antarctic Expedition. This project was led by Dr. Antoni Ballester on board of the Argentinian research vessel, R/V Almirante Irizar, to study the Antarctic phytoplankton. More recently, she was specially enthusiastic about her privileged op-

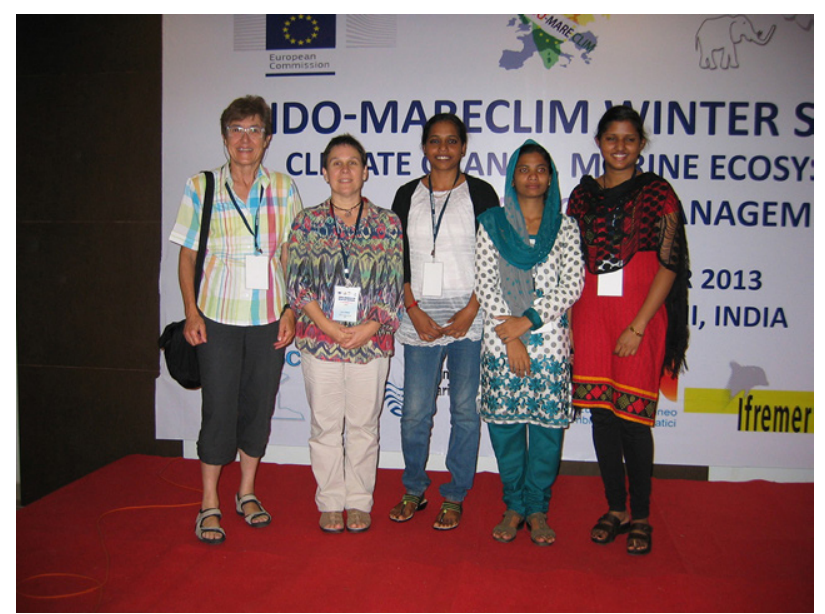

Fig. 4. - Marta Estrada in the Indo-Mareclime Summer Course (Kochi, India), November 2013, with Elisa Berdalet (on her left) and three students.

portunity to participate in Arctic (CASES and CFL), again, in Antarctic (PEGASO) cruises and in one of the transects of the "Malaspina 2010 Expedition," a circumnavigation oceanographic survey commemorating the 200 year-old expedition of Alessandro Malaspina and José Bustamante to America, Asia, and Oceania. Looking back, Marta has noticed the enormous advances in science, particularly in oceanography, that have occurred since she started her career, and she has felt fortunate to have had the opportunity to contribute to these progresses.

In 1987, the IIP, following a progressive and internal transformation from the initially focussed research on fisheries to the integration of Marine Biology, Physics and Geology disciplines changed its name to the Institut de Ciències del Mar (ICM, Marine Sciences Institute). Throughout the 80's, Marta was the Head of the Marine Biology and Oceanography Department of the ICM. She had become our natural leader, gaining the respect of everybody, without having to impose anything. During the 1995-1997 years, Marta served as Acting Director of the ICM. Marta conceived the

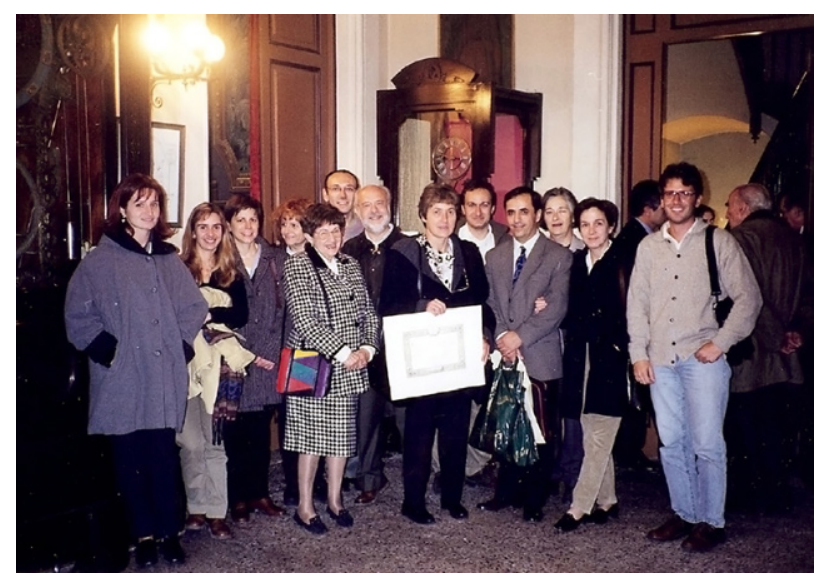

Fig. 5. - Marta Estrada in November 2000, the day when she became a member of the Royal Academy of the Sciences and the Arts of Barcelona, accompanied by several colleagues at the ICM. From left to right: M. Sala, L. Arin, C. Marrasé, D. Vaqué, E. Saiz, M. Alcaraz, A. Calbet, C. Pedrós-Alió, D. Blasco, C. Enríquez de Salamanca and M. Latasa. Feli, Marta's mother is next to her. 
Department as well as the ICM as a common house, where everything is shared by its members. Aware of the difficulties in conducting research in Spain when she was young, she has always maintained and transmitted to us the twin ideas of austerity and generosity. This is one of Marta's most important legacies, one that is especially helpful in facing the hard times of the present. Increasingly, Marta is often requested to share her wise advice. She is a consistent reference for the research and human issues in our scientific network at ICM-CSIC.

In addition to investigations, Marta supervised several $\mathrm{PhD}$ students and postdoctoral researchers, and has been involved in teaching, both lecturing in $\mathrm{PhD}$ programmes on Global Change (University Menéndez y Pelayo) and in phytoplankton, microbial ecology (e.g. University of Barcelona and of Las Palmas de Gran Canaria), and other courses (e.g. Indo-Mareclim Winter School, Margalef Summer Colloquia). Often she is invited to International Symposia and outreach activities (conferences, discussions, round tables...) where she always impresses the public with the depth and the width of her knowledge on science and many other issues.

Marta Estrada has been a member of many international committees including the ICES Advisory Committee on Marine Pollution (1989-1992), the ADENA-WWF World Wildlife Foundation (1990-1992), the Working Group 97 of the Scientific Committee on Oceanic Research (SCOR), the "Physiological Ecology of Harmful Algal Blooms" (1992-1998), the Scientific and Steering Committee (1998-2000) of the International programme Global Ecology and Oceanography (GEOHAB) of Harmful Algal Blooms (SCOR/IOC-UNESCO), Spanish Representative at the SCOR (ICSU), Experts Groups in Global Change of Catalonia, the Jury of the "Ramon Margalef Prize of Ecology", the "Institute of Catalan Studies, IEC" (since 2003), among others.

Marta's work has been acknowledged outside the oceanography. In 1969, she received the Lazo de la Orden Civil de Alfonso X el Sabio in Spain. In 1992, she was honored with the Tregouboff Prize of the Académie des Sciences de París (1992). In 1999, she was nominated member of the Royal Academy of the Sciences and the Arts of Barcelona. In 1995, the Generalitat of Catalonia granted Marta with the Narcís Monturiol Medal to the scientific and technology merits and in 2004 she was awarded with the Creu de Sant Jordi for her overall scientific trajectory, specially centered in the phytoplankton ecology and in 2005 the Medal of the City of Granollers.

Marta is a well-liked and respected member of their research teams. She is held in such high esteem, because is brilliant, pleasant, kind, considerate, she speaks several languages, and is very hard working. In addition, because she would often become sea-sick on the ships, but would keep on working regardless of what her stomach was feeling, she astonishes everyone. Marta is considered a super woman. On philosophical issues, Marta has a critical vision of the situation of the women in science. For instance, recently, in her contribution in Kappel (2014) she noted that "the finding that the proportion of women becomes lower up the ladder toward top positions indicates that discrimination must persist. Balancing scientific activity (or any other outside work, for that matter) and family needs (be it for the care of young children or of elder parents) continues to be a challenge that falls disproportionately on women. However, the situation is improving, and I would say that for an overwhelming majority of women scientists, a research career has been a worthwhile path that they would choose again if given the opportunity."

When asked about retirement (mandatory in Spain at 70), she says that so long as people are in good health, one never really needs to retire from creative activities such as research. She is looking forward to continued scientific collaboration with her younger colleagues (without the bureaucratic part!). To any aspiring oceanographer, women or man, she will always say "just go ahead." There will be difficulties, but also rewards, the satisfaction of contributing to the world's scientific knowledge.

\section{ACKNOWLEDGEMENTS}

We are very grateful to Dr. T.T. Packard for gathering information on the 1970-1980 period that Marta Estrada actively collaborated with USA researchers.

\section{REFERENCES}

Blasco D., Estrada M., Jones J.H. 1980. Relationship between the phytoplankton distribution and composition and the hydrography in the northwest African upwelling region near cabo Corbeiro. DeepSea Res. Part A, Oceanog. Res. Papers 27: 799-821. http://dx.doi.org/10.1016/0198-0149(80)90045-X

Estrada M. 1980. Phytoplankton biomass and production in the upwelling region of NW Africa. Relationships with hydrographic parameters. Mar. Biol. 60: 63-71 http://dx.doi.org/10.1007/BF00395607

Font P., Ramon E. 2003. Josep Estrada, pioner de l'arqueologia a Granollers i al Vallés. Monografia Lauro 22-23: 75-79.

Kappel E. (ed.). 2014. Women in Oceanography. A decade later. Oceanography 27(4) Supplement: 1-258.

http://www.tos.org/oceanography/assets/images/content/27-4_ supplement.pdf

Margalef R., Estrada M. 1981. On upwelling, eutrophic lakes, the primitive biosphere and biological membranes, In: Richards F.A. (ed.), Coastal Upwelling. American Geophysical Union, Washington DC, pp. 522-529. http://dx.doi.org/10.1029/CO001p0522 